\title{
Prior Knowledge in Mathematics Learning
}

\author{
Eka Fitria Ningsih ${ }^{1 *}$, Endah Retnowati ${ }^{2}$ \\ ${ }^{1}$ Universitas Negeri Yogyakarta, Yogyakarta, Indonesia, \\ E-Mail: ekafitria.2019@student.uny.ac.id \\ ${ }^{2}$ Universitas Negeri Yogyakarta, Yogyakarta, Indonesia,
}

\begin{abstract}
Learning is the process of building new knowledge by linking existing knowledge. Meaningful learning is learning that maximally utilizes prior knowledge of students. This article aims to explore how to use initial knowledge to build new knowledge on the material of the greatest common factor. The description of initial knowledge refers to the previous material, which is the material of the greatest common factor. Teachers need to pay attention to the types of knowledge on the material the greatest common factors include factual, procedural and conditional knowledge to determine learning strategies
\end{abstract}

Keywords: prior knowledge, mathematics, learning, cognitive

\section{Introduction}

Constructivism views students as learners who are actively building knowledge. Research trends in Indonesia use constructivism as a basis for learning development. The design of the education curriculum in Indonesia is also student-centered. The construction itself consists of two namely cognitive construction and social construction. Piaget [1] was the originator of cognitive construction while Vigostky was the originator of social construction.

Problem-solving learning and RME are part of learning with social construction. In this learning, students interact with colleagues to solve problems. Through this interaction, of course, students are at least able to develop their ability to work together. This ability is one part of the objectives of national education in Indonesia. Gutek explained that learning activities oriented to problem-solving contain social and intellectual possibilities that contribute to student growth. Progressive educators are teachers who are skilled in connecting the internal conditions of students from the experience needs, interests, goals, capacities, and desires with objective conditions [2].
Teachers as part of education have one of the tasks is to become a learning designer. Learning planning certainly requires innovation, creativity and adequate knowledge. Innovation in learning can be in the form of the use of learning models. Besides, the use of instructional media to help visualize problems is part of innovation. There has been researched on the use of media as well as learning models for primary school level on the largest material fellowship factor. Several studies have developed learning media for this material such as the use of dacon media [3]. The use of problemsolving models for the biggest fellowship material [4].

It is necessary to map and analyze the characteristics of the material, the environment, and other factors before deciding to choose a particular media or learning model. Identification of material characteristics related to the second type of construction, namely cognitive constructs. Cognitive construction is related to how students can build and develop their knowledge. The definition of learning according to this flow is the process of building new knowledge by linking existing knowledge [5].

Existing research has developed many media and learning models for learning mathematics in elementary schools. This shows part of innovation in learning 
mathematics. However, there is no information on how the material characteristics of the biggest alliance factors for elementary school-age children. Graviss \& Greaver's research shows that the greatest common factor is a difficult topic for students. One that is possible because students are confused about understanding factors and multiples [6]. Preschool and elementary school children have substantial capacity to learn mathematics, but many children do not have the opportunity to do so [7]. An effort to make learning mathematics difficult through material analysis. The analysis includes how the material is related to prior knowledge. Identification of the type of knowledge that is the purpose of learning. Besides, it is also important to look at environmental aspects that are related to the material. Thus, it is important to conduct a study of the exploration of the material characteristics of the greatest common factorization. The hope, this information can be useful for prospective educators in designing mathematics learning.

\section{Utilization of Long Term Memory in Learning}

In choosing teaching methods the teacher should not choose arbitrarily. Planning learning methods should be based on consideration of individual differences, which can provide feedback and student initiative to solve problems. In other words, the success or failure of learning activities, one of the determining factors is the effective use of teaching methods. Information processing occurs in the interaction between internal conditions and external conditions of individuals. Internal conditions, namely the state in the individual to achieve learning outcomes and cognitive processes that occur within the individual. While external conditions are stimuli from the environment that affect individuals in the learning process. Information processing refers to how to collect/receive stimuli from the environment, organize data, solve problems, find concepts, and solve problems, and use verbal and non-verbal symbols.

Sensory memory records information or stimuli that enter through one or a combination of the five senses, namely visually through the eyes, hearing through the ears, smell through the nose, taste through the tongue, and palpation through the skin. If students do not pay attention to information or stimuli of the teacher, students will forget, but if they pay attention then the information moves to the short-term memory system. Short-term memory systems store information or stimuli for about 30 seconds, and only about seven chunks of information (chunks) and store in the short-term memory system at a time [8].

The representation of knowledge in memory has produced a much clearer picture of the planning of knowledge structures in students. Progress has occurred in understanding the importance of procedures and the influence of prior knowledge on processing new information [9]. Bruning explained that long term memory is the permanent storage of information about information [10]. In learning, student interaction with the environment produces this information in the form of knowledge. Experience in sensory memory is processed in working memory. Sensory memory is the first memory that receives stimulus from the environment and is limited [5]. Sperling's research confirms that the limitations of the visual sensory motory are very limited as indicated by the results of his research that students are only able to process seven to nine information (number of letters) at the given time [10].

Visual and verbal presentation of information aims to maintain information long enough in working memory so that it can be further processed cognitively [11]. Activation of existing knowledge in long term memory allows us to recognize certain objects. Thus, linking the knowledge that has been stored in long term memory with the information to be conveyed becomes important. Recognizing and linking objects with those that are already owned will make meaningful learning. It is important to safeguard the information that is already stored in our memory. Making meaningfulness and organizing the existing knowledge in memory will be the determinant in the next process of storing knowledge. Understanding how long term memory works can certainly help in designing learning so students can access and use the basic knowledge they have to construct new knowledge.

Cognitive psychology classifies knowledge into three categories [10]. Declarative knowledge is knowledge of "what" facts. For example, declarative knowledge in mathematics, namely the concept of division is repetitive reduction. FPB is the biggest common factor. Procedural knowledge is knowledge about procedures or how to do certain "how" activities. The procedural knowledge that we have for example regarding the procedure of division by stacking down. The third category is conditional knowledge. This knowledge is related to when and why to use declarative and procedural knowledge. For example, students already understand the concept of the greatest common 
factor and can find the greatest common factor of two numbers. However, students are still not able to apply this knowledge to solve problems in real life, for example determining the highest amount that can be made. Conditional knowledge is needed to help students use declarative and procedural knowledge effectively.

\section{Activation of Long Term Memory}

The concept of ideas about something that provides a means to understand the world. Often, a concept can be captured in one word, like the symbol "3" which means three. Each concept is in turn related to other concepts, such as three, which deal with integers, odd, or prime. As we can imagine, people collect many concepts during their lives. Certainly, there are ways to organize all of those concepts. One way to organize it is to use categories. A category is a group of items where different objects or concepts can be placed in common because they share some common features, or because they are all similar to a particular prototype [12]. We will explore how concepts can be organized through hierarchically arranged semantic networks, as well as schemes, which are mental frameworks of knowledge that encompass some interrelated concepts.

Long term memory contains knowledge, hereinafter referred to as prior knowledge. Prior knowledge becomes an important part to understand in planning learning. The description of the information in long term memory as prior knowledge for provision in constructing further knowledge (figure 1).

PRIOR KNOWLADGE

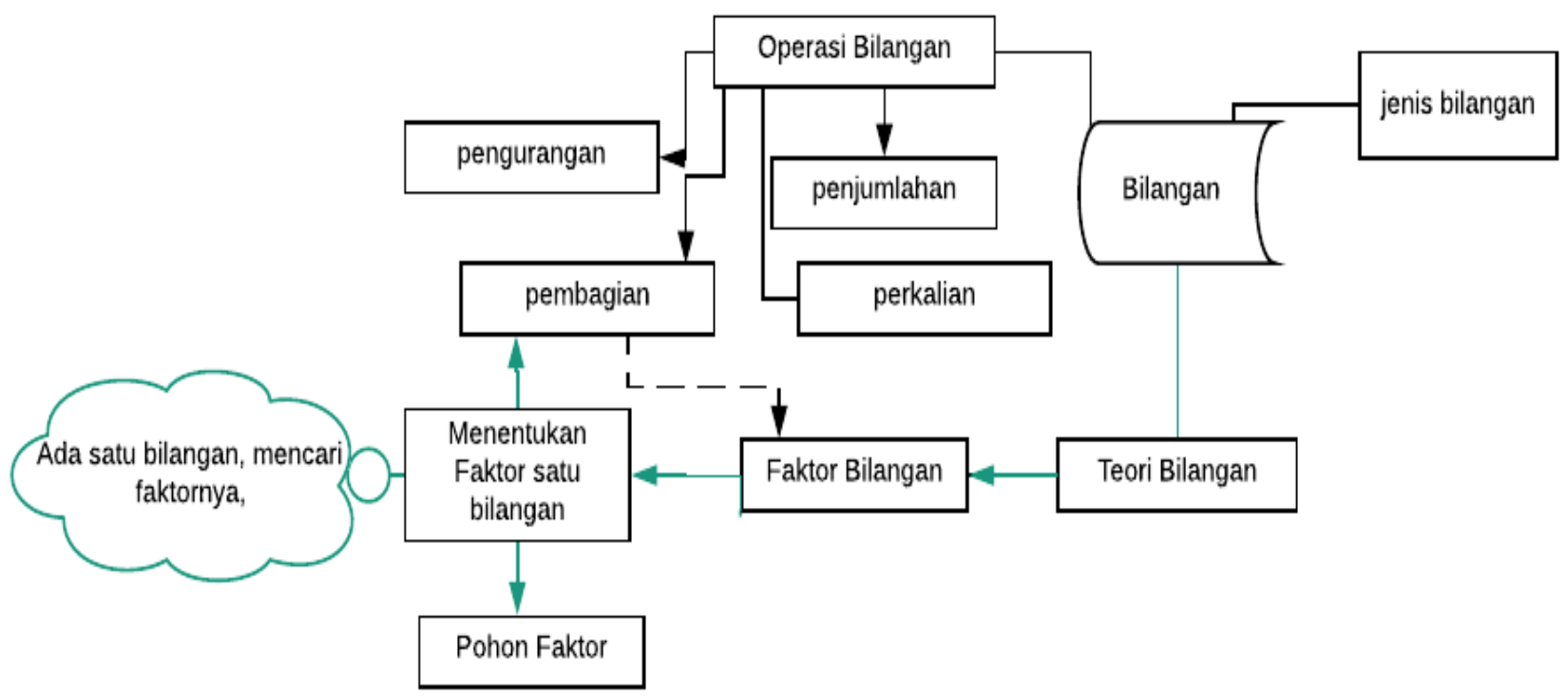

Figure. 1 Prior Knowladge

Material about the operation of multiplication and division numbers becomes the prerequisite knowledge of the greatest common factor. The concepts of multiplication and division are stored in memory in the form of conceptual knowledge. In the apperception section of teaching the greatest common factor is the teacher needs to activate student knowledge about the division of both the concepts and procedures. Next, the teacher introduces the concept of number factors. The definition of a number factor will be stored into conceptual knowledge. In this section, the teacher needs to consider strategies so that this knowledge is easy to organize in memory and is meaningful. In primary school-aged children, the term "factor" is still foreign to hear especially for students who are in areas that rarely use formal Indonesian. Information storage strategies can use mnemonics. Mnemonic is a strategy that can help someone to remember information by making encoding. One mnemonics technique that can be used to store information on the word "factor" is the keyword method. The teacher can help students create the 
"factor" keyword by linking the word "division" that is already stored in their memory.

Concepts and categories can be divided in various ways. One commonly used difference is between natural categories and artifact categories. Natural categories are groupings that occur naturally in the world, such as birds or trees. Artifact categories are groupings that are designed or created by humans to serve a specific purpose or function. Concepts, by contrast, are not always stable but can change. They are explained not in words but phrases. Their content varies depending on the context. Of course, there are differences in the mention of the terms from each region. Concepts seem to have a basic level (sometimes called the natural level) of specificity, a level in the hierarchy that is preferred over other levels [12].

The next stage in determining the factor of one teacher number can introduce methods that can be used. There are two basic ways to find the biggest common factor of two numbers: the intersection method and the main factorization method [6]. Knowledge of these methods will be stored as procedural knowledge. Learning for elementary school children certainly needs to be brought to play and fun activities. The use of colorful cardboard. The teacher can also create active discussion by making students able to express the ideas they have. Teachers 'attention to all students so that all students' needs and difficulties can be facilitated. Students can master the material but each has a different ability in reception.

\section{Connections to New Knowledge}

According to Lesgold, There are too many details and the presentation is too confusing to store information in short-term memory without the aid of a good scheme [9]. This certainly becomes clear signs for a teacher to help with the preparation of a good scheme. Students who do not have a deep understanding of the material because acceptance is not followed by efforts to link knowledge possessed [5]. Of course, the sensitivity of the teacher is indeed needed to find strategies that help in connecting knowledge in memory. The stages of understanding material for number factors have been explained. Of course, the pleasant delivery of material has a great influence on motivation to follow the next lesson. The teacher needs to make sure again about the mastery of the material about number factors before moving to the material of the greatest common factor.

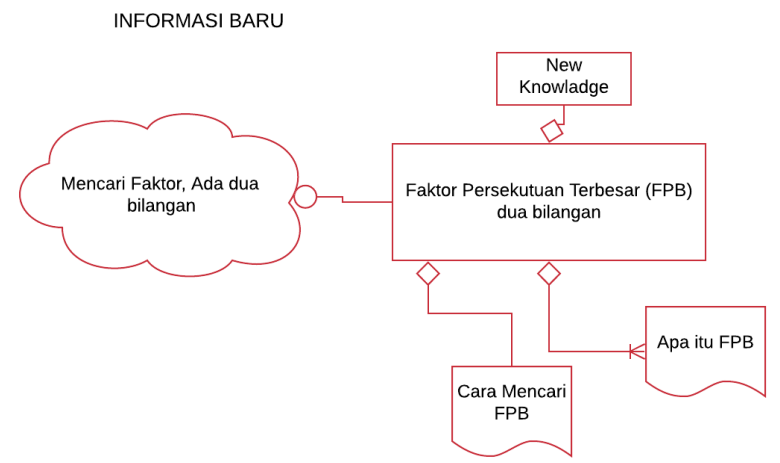

Fig. 2. New knowledge

Having previously been introduced to the term "factor" in this section students are introduced to the term "fellowship". Of course, not all children understand the meaning of this word. Storage of meaning of alliance in knowledge can use imagery strategies. The imagery strategy links information to be stored by imagining certain events that are meaningful in students so that they are easy to remember [10]. One alternative teacher can make role-playing activities before introducing the term partnership. In these role activities, students are directed to do the role of warfare. During the war, there were allied (joint) activities. Then the teacher reaffirms the allied meaning and its relation to the term alliance to be learned. Role-playing for elementary school-age children can certainly make learning fun. According to Pietarinen, the entertainment side of the game can motivate students to learn so that there is an increase in students' understanding of the concepts contained in the game [13]. People learn best when they have strong and direct motivation to gain new knowledge, and when they have fun [14]. also stressed through role-playing activities students feel involved and can interpret deeply about an event. Alternatively, the teacher can associate the term "ally" with historical subjects. In the history lesson, there is material about the struggle for independence. In these efforts, there are allied activities with opponents for example. With the ability previously possessed by students to determine the biggest factor of one number, then students are directed to determine the greatest common factor of two numbers (see fig. 2). The teacher can use abbreviations to make it easier for students to remember the greatest common factor. Usually abbreviated as FPB acronym. In this FPB determination procedure, the teacher should provide training in advance rather than directly providing the context of 
daily life problems. This is because the ability to interpret a story problem for elementary school-age children is still difficult to add even if they can identify problems they cannot solve. Thus, the practice of using numbers first is more effective.

Competencies that must be achieved after following the FPB material certainly students can solve problems related to daily life. Students' mastery of FPB concepts and procedures from two numbers becomes a capital to enter the context of problem-solving in daily life. Reallife problems that can be presented in classroom learning related to FPB usually make the most of the packets of several components. Bridging the context of the problem with the story of FPB certainly not so easy. Lesgold asserts that the problems presented in semantic modalities are usually felt to be difficult due to leniency, ambiguity, and language openness. The context of the problem can occur both from the situation and the mobilization of semantic memory needed to arrive at a "closed" interpretation of the problem text. Many mistakes occur when students try to solve reasoning problems can indeed be marked as an inability to come to representations of problems that can be applied [9]. The importance of the teacher to accompany the students to build an understanding that FPB is related to the possibility of many packages that can be made. Making the most asserted packages is the "biggest" part of the FPB. Filling each package with the same contents relates to the meaning of "fellowship factor". Knowledge about the use of FPB in solving story problems is to be stored in memory into conditional knowledge. The teacher's role is very important to help students organize and give meaning so that the knowledge they already have can be stored well in memory.

The difficulty faced by students usually lies in the ability of conditional knowledge. Students can determine FPB from two numbers but may not be able to determine when to apply these abilities in problemsolving. The use of mnemonic is also important to make it easier to store information. The teacher can help students create keywords to help them remember.

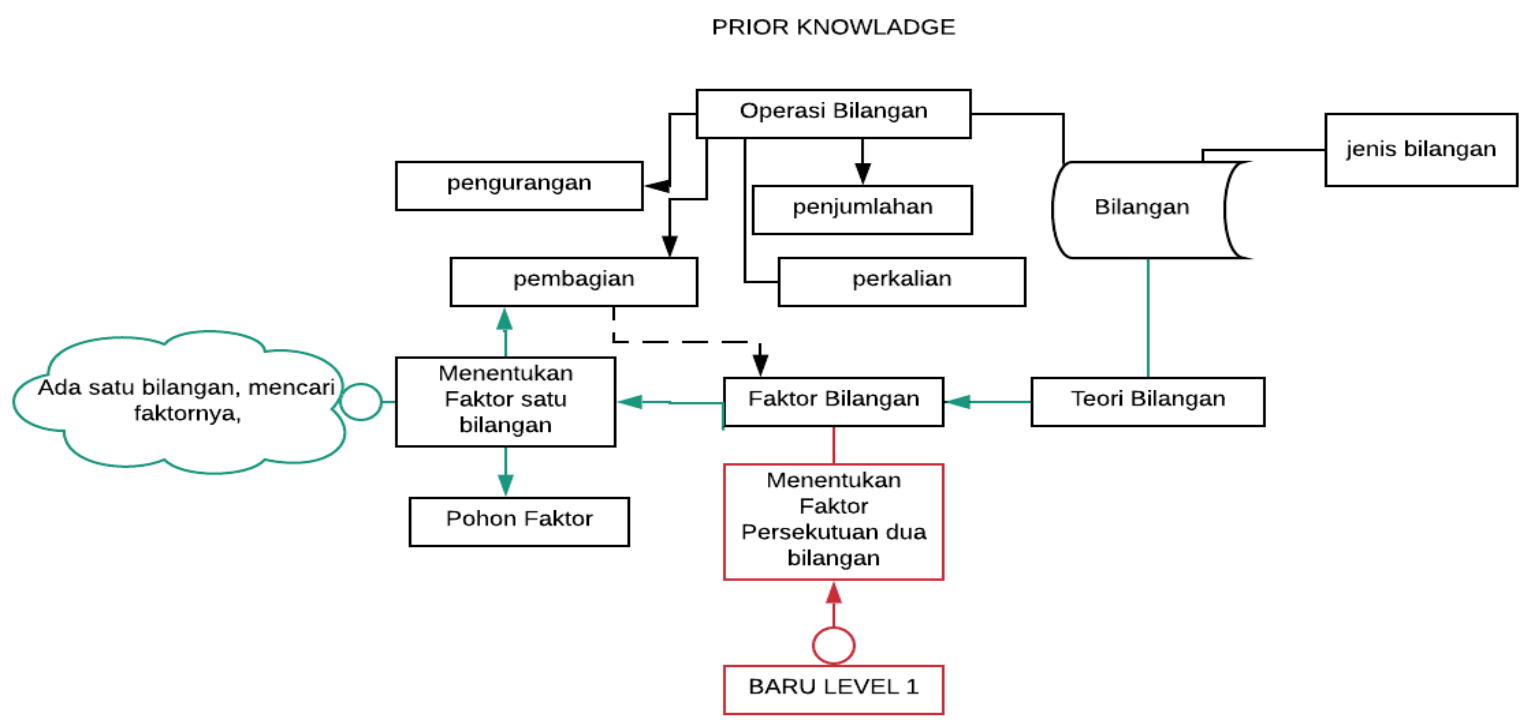

Fig. 3. Connection among prior knowledge and new knowledge

This explanation is an ideal view of the student's cognitive system when getting information about this greatest common factor. However, some factors influence the smoothness in this process. This explanation is ideally for students who already have good attention or focus while studying. Most individuals cannot do one or two things at the same time [10]. Practices in schools, students must be given as much of this information while on the other hand outside disturbances can change students' attention to learning. For elementary school-age children, of course, they are still at the stage of playing so a teacher needs to make things that attract students' attention in learning. Progressive teachers must be able to make interesting things at the center of learning [2]. In the teaching implications of Schunk explained that it is important to pay attention to the portion and speed in presenting the material because of the limitations of working memory 
in individuals. Presentation of information visually and verbally can be done to maintain information long enough in working memory so that it can be further processed cognitively [11]. Implications in designing learning methods include learning the material presented hierarchically, knowledge is stored well so that deep understanding and facilitating schema automation in knowledge that has been stored needs to be trained repeatedly so that it can be raised in working memory automatically when solving a problem [15].

\section{Conclusion}

The teacher's skill in designing a learning one that becomes an important part is the ability to link the knowledge that is already owned by students in the process of constructing new information. Knowledge in prior knowledge consists of factual, procedural and conditional knowledge. An in-depth mapping of the largest material content component of the alliance will help the teacher in developing the learning strategies used. The strategy of remembering information with mnemonics with the key words method can be used to remember the term "factor" which is difficult for elementary school students to understand. Imagery strategies can be used by teachers to help students remember about "fellowship". Besides, the teacher can use a fun learning model that can attract students' attention.

\section{References}

[1] M. Y. Zhou and D. Brown, Educational Learning Theories. Retrieved from (link), 2017.

[2] G. L. Gutek, Philosophical Alternative inEducation. Columbus: OHIO: Charles E. Merril Publishing Company, A Bell \& Howell Company, 1974.

[3] D. Lesthary, B. Tampubolon, and A. Salimi, 'PENINGKATAN HASIL BELAJAR SISWA PADA PEMBELAJARAN MATEMATIKA MENGGUNAKAN MEDIA DAKON BILANGAN DI SD', J. Pendidik. dan Pembelajaran Khatulistiwa, vol. 3, no. 11, Nov. 2014.

[4] I. Indiyah, 'Peningkatan Hasil Belajar Matematika Materi KPK Dan FPB Melalui Penerapan Problem Solving Approach Pada Siswa Kelas VI SDN 03 Manisrejo Kota Madiun', J. Ilm. Pengemb. Pendidik., vol. 6, no. 1, pp. 18-24, Feb. 2019.

[5] E. Retnowati, Psychology of Mathematics Learning. Yogyakarta: UNY Press, 2019.

[6] G. Musser, 'National Council of Teachers of Mathematics Principles and Standards for School Mathematics Principles for School Mathematics', p. 1078, 2007.
[7] D. H. Clements and J. Sarama, 'Early childhood mathematics intervention.', Science, vol. 333, no. 6045, pp. 968-70, Aug. 2011.

[8] M. Bhinnety, 'Struktur Dan Proses Memori', Bul. Psikol., vol. 16, no. 2, pp. 74-88, 2015.

[9] A. M. Lesgold and J. W. Pellegrino, Cognitive Psychology and Instruction. New York: Springer, 1977.

[10] R. H. Bruning, G. J. Schraw, and M. M. Norby, Cognitive Psychology And Instruction, Fifth Edit. Boston: Ally \& Bacon, 2011.

[11] D. H. Schunk, Learning theories: An educational perspective. 2012.

[12] R. J. Sternberg and K. Sternberg, Cognitive Psychology. Cengage Learning, 2012.

[13] A. Wijaya, 'Permainan ( Tradisional ) untuk Mengembangkan Interaksi Sosial, Norma Sosial dan Norma Sosiomatematik pada Pembelajaran Matematika dengan Pendekatan Matematika Realistik', 2009.

[14] W. A. Wan Fatimah, S. Afza, and A. L. Mohd Hezri Amir, 'Role-playing game-based learning in Mathematics.', Electron. J. Math. Technol., vol. 4, no. 2, pp. 185-196, 2010.

[15] E. Retnowati, 'Keterbatasan Memori dan Implikasinya dalam Mendesain Metode Pembelajaran Matematika', in Prosiding Seminar Nasional Matematika dan Pendidikan Matematika, 2008. 